短報

\section{植食性魚類ノトイスズミKyphosus bigibbus の消波ブロックへの蝟集とその季節変化}

\author{
門田 立, ${ }^{*}$ 清本節夫, ${ }^{1}$ 福田紘士, ${ }^{2}$ 吉村 拓 $^{1}$
}

(2016 年 5 月 2 日受付, 2016 年 9 月 21 日受理, 2016 年 11 月 25 日 J-STAGE 早期公開)

1 (国研) 水産研究 - 教育機構西海区水産研究所, 2 宮崎県水産試験場

Temporal patterns of aggregation formation around wave-dissipating blocks in the grey sea chub Kyphosus bigibbus

TATSURU KADOTA, ${ }^{*}$ Setuo KIYOMOTO,${ }^{1}$ HIROSHI FUKUDA ${ }^{2}$ AND TAKU YOSHIMURA ${ }^{1}$ ${ }^{1}$ Seikai National Fisheries Research Institute, Japan Fisheries Research and Education Agency, Taira, Nagasaki 851-2213, ${ }^{2}$ Miyazaki Prefectural Fisheries Research Institute, Aoshima, Miyazaki 889-2162, Japan

キーワード：磯焼け, 除去, 潜水目視調查, 藻食性魚 類, ノトイスズミ, 藻場造成

ノトイスズミKyphosus bigibbus は南日本や琉球列島 を含むインドー西太平洋に分布するイスズミ科魚類で， 成長すると全長 $60 \mathrm{~cm}$ に達することが知られている。1) 本種は主に褐藻類を拱慨する植食性魚類で, $\left.{ }^{2}\right)$ アイゴ Siganus fuscescens やブダイ Calotomus japonicus と並ん で海藻類への採食圧が高い種と考えられている。 のため本種は, 藻場の衰退が著しい九州沿岸域におい て, 藻場の保全や造成を目的とした除去の対象種になっ ている。而しかし，海藻類に対する本種の影響が注目さ れ始めたのが比較的近年であるため, 海藻類への採食圧 等の定量的評価は行われておらず，個体数管理に有益な 生態情報も十分には蓄積されていない。

本邦に打ける本種の生態研究は九州西岸域で進められ ている。山口ら7) はバイオテレメトリー技術を用いた大 型個体（全長 37-59 cm）の追跡調查を長崎県の野母崎 において実施し, 秋季（11月から 12 月）に本種が毎日 藻場に来遊することを報告している。また，水温が低く なる 1 月以降の冬季には, 信号の受信頻度や受信場所 の変化から, 行動パターンが秋季と異なる可能性を指摘 している。冬季の行動パターンについては, 近年, 壱岐 島の漁港の消波ブロック周辺に大型個体（全長 28-60 $\mathrm{cm}$ ）が蝟集することが報告されているものの, 6,8) 定量
的なデータは少なく, 本種が蝟集する要因については十 分に検討されていない。また, 壱岐島以外の海域におけ る本種の蝟集状況は全く分かっていない。蝟集時に刺網 を設置することで本種を漁獲できることが確認されてい ることから，6,8) 蝟集の条件が解明できれば，本種の個体 数管理の効率化に資すると考えられる。

著者らは, 2010 年 4 月 16 日に長崎県壱岐市和歌漁

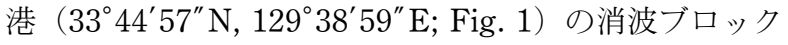
周辺で本種200個体以上が蝟集していることを確認し た。そこで, 本種の消波ブロック周辺での蝟集実態を明 らかにするため, 和歌漁港に打いて 2010 年 4 月から 2015 年 2 月にかけて潜水調查を不定期に計 51 回実施 した。調查では 8 時から 17 時の間に和歌漁港の消波ブ ロックに沿って約 $50 \mathrm{~m}$ の範囲を 15 分間程度遊泳し, 蝟集している個体の全長及び大型個体（全長 $30 \mathrm{~cm}$ 以 上の個体）の個体数を目視により推定した。本種は消波 ブロックの内外を行き来することがあるため正確な個体 数の計数が困難なことから, 蝟集している大型個体の一 部を計数した後, 計数した群れの大きさから群れ全体の 個体数を推定した。個体数の推定は 1-9 個体の場合は 1 個体単位で, 10 個体以上は 10 個体単位で, 50 個体以 上は 50 個体単位で， 200 個体以上は 100 個体単位で概 数を記録した。なお， 200 個体以上のデータは実際との 誤差が大きいと考えられたため，200 個体以上のデータ はすべて「200 個体以上」とまとめ, 解析を行った。ま た，水深 $3 \mathrm{~m}$ 地点に設置した水温ロガー（ATD-HR, JFE アドバンテック社）により調査期間中の海水温を 10 分間隔で記録した。次に，九州沿岸の他の海域にお ける本種の蝟集状況を確認するため, 2009 年 5 月から 2015 年 3 月にかけて長崎県長崎市長崎漁港 $\left(32^{\circ} 48^{\prime} 21^{\prime \prime}\right.$ $\mathrm{N}, 129^{\circ} 44^{\prime} 39^{\prime \prime} \mathrm{E}$ ), 野母漁港 ( $32^{\circ} 34^{\prime} 40^{\prime \prime} \mathrm{N}, 129^{\circ} 45^{\prime} 20^{\prime \prime}$ $\mathrm{E})$, 宮崎県日向市平岩港 $\left(32^{\circ} 22^{\prime} 30^{\prime \prime} \mathrm{N}, 131^{\circ} 38^{\prime} 8^{\prime \prime} \mathrm{E}\right)$ 及び串間市都井漁港 $\left(31^{\circ} 23^{\prime} 11^{\prime \prime} \mathrm{N}, 131^{\circ} 18^{\prime} 19^{\prime \prime} \mathrm{E}\right)$ の消 波ブロック周辺で潜水調查を実施した（Fig. 1)。長崎 漁港では消波ブロックに沿って約 $140 \mathrm{~m}$ の範囲を 20 分 間程度, 野母漁港では約 $150 \mathrm{~m}$ の範囲を 20 分間程度, 平岩港では約 $100 \mathrm{~m}$ の範囲を 30 分間程度, 都井港では 約 $200 \mathrm{~m}$ の範囲を 1 時間程度遊泳し, 和歌漁港々同様 の方法で大型個体の個体数を推定した。長崎漁港では近 隣の水深 $7 \mathrm{~m}$ の地点 $\left(32^{\circ} 48^{\prime} 51^{\prime \prime} \mathrm{N}, 129^{\circ} 43^{\prime} 47^{\prime \prime} \mathrm{E}\right)$, 野 母漁港では近隣の水深 $6 \mathrm{~m}$ の地点 $\left(32^{\circ} 34^{\prime} 5^{\prime \prime} \mathrm{N}, 129^{\circ} 44^{\prime}\right.$ $\left.28^{\prime \prime} \mathrm{E}\right)$ に水温ロガー（TidbiTv2, Onset Computer Cor-

C)2017 公益社団法人日本水産学会/The Japanese Society of Fisheries Science

* Tel : 81-95-860-1600. Fax : 81-95-850-7767. Email : kadota74@affrc.go.jp

電子付録付報文：J-STAGE オンライン版（http://doi.org/10.2331/suisan.16-00035）にて本稿の関連資料を公開。 


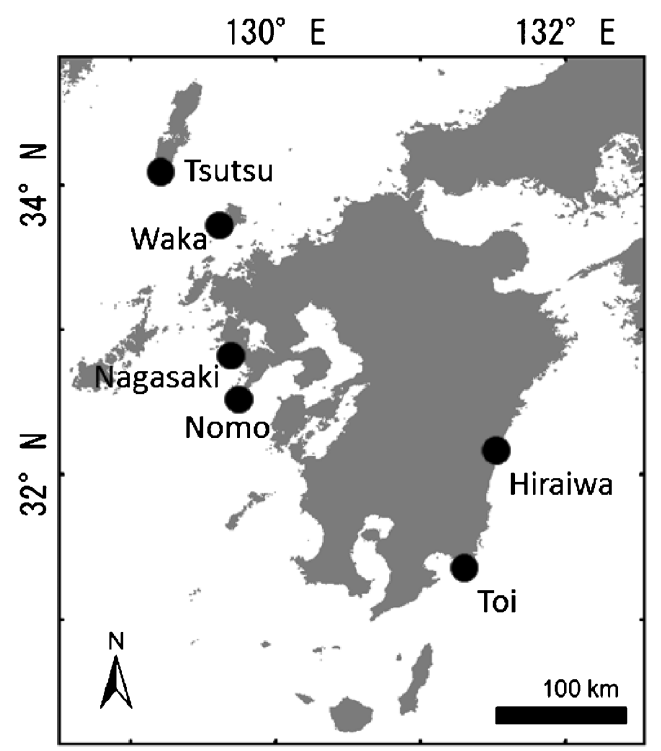

Fig. 1 Sites where aggregation formation of Kyphosus bigibbus was observed. Data of Tsutsu and the other data were based on personal communication by Hyodo and the present study, respectively.

poration, Bourne, MA, USA) を設置し，調査期間中の 水温を 30 分間隔で記録した。また，平岩港及び都井漁 港ではダイビングコンピューター (DiveAdvisor， 日本 潜水機）を用いて水温を記録した。

和歌漁港の消波ブロック周辺で 51 回の調查を行い, その内 25 回の調查で, 大型個体 200 個体以上の蝟集を 確認した（Fig. 2a；電子付録 Appendix 1)。200 個体以 上の蝟集を確認した観察頻度（200 個体以上の蝟集を確 認した日数/観察を実施した日数）は 1 月から 4 月にか けて高く $(0.89, n=18), 5$ 月から 7 月にかけて減少し $(0.54, n=13), 8$ 月から 12 月はさらに低くなった $\left(0.10, n=20 ; \chi^{2}\right.$ 検定, $\left.p<0.01\right)$ 。この内, 推定の誤差 が大きいと考えられるが，500-1000 個体の巨大な蝟集 の出現は 1 月から 6 月の間に限られていた。また, 蝟 集の規模は異なるものの, 他の 4 つの調査地点に抢い ても冬から春にかけて本種の蝟集を確認した（Fig. 2be)。さらに，2005 年 1 月 6 日には対馬市豆酘（Fig. 1) の消波ブロック周辺に扔いても本種と思われるイスズミ 科魚類の蝟集が観察されている（侑崎陽潜水兵働氏, 私 信 ; 電子付録 Appendix 1)。これらの結果は, 九州西部 及び南東部の沿岸の各地で本種が冬季から春季に消波ブ ロック周辺に蝟集する可能性が高いことを示唆する。

和歌漁港では, 200 個体以上の蝟集は水温が $12.6-$ $25.7^{\circ} \mathrm{C}$ の間で出現し， $16.9^{\circ} \mathrm{C}$ 以下の期間に高頻度で出 現した（Fig. 3)。この内，500-1000 個体の巨大な蝟集 の出現については水温が $12.6-20.6^{\circ} \mathrm{C}$ の期間に限られて いた。200 個体以上の蝟集の出現の有無と和歌漁港地先 の水温の関係について，二項分布を仮定した一般化線形

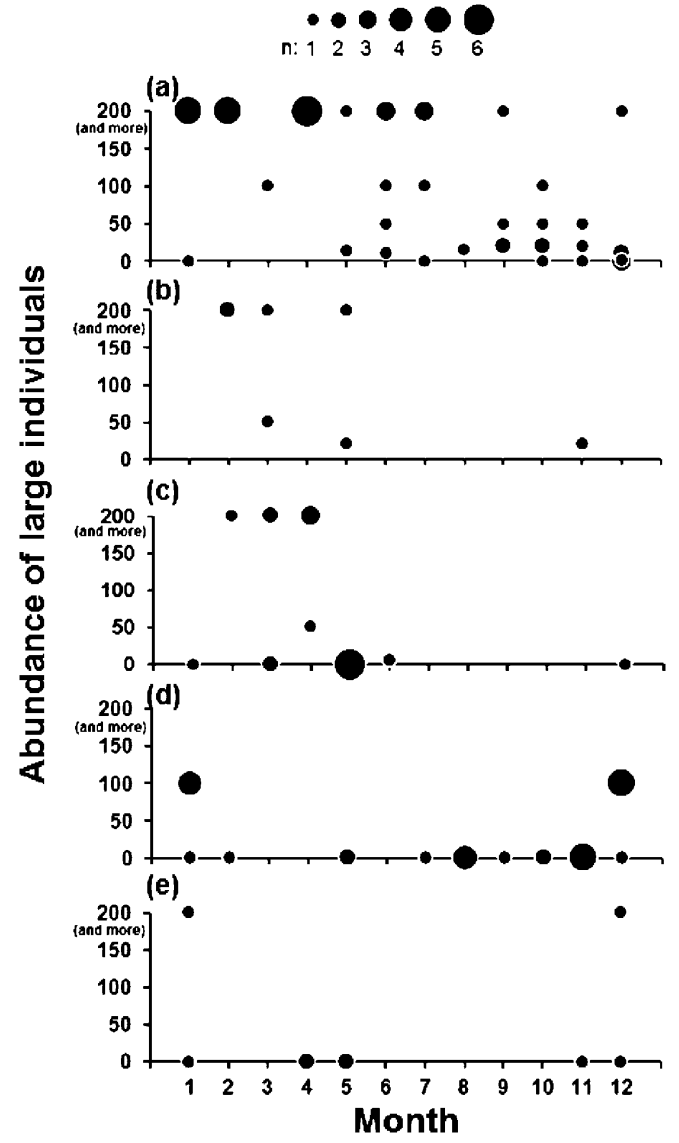

Fig. 2 Abundance of large Kyphosus bigibbus found each month around wave-dissipating blocks at each study site. Symbol sizes represent the difference in number of observations. (a) Waka, (b) Nagasaki, (c) Nomo, (d) Hiraiwa, (e) Toi.

モデルを用いて解析したところ，有意な相関が認められ た $(p<0.01)$ 。その他の地点に抢ける蝟集観察日の水 温は, 野母漁港で 13.8-15.7 ${ }^{\circ} \mathrm{C}$, 長崎漁港で 13.6-20.4 ${ }^{\circ} \mathrm{C}$, 都井漁港で $16^{\circ} \mathrm{C}$, 平岩港で $14-16{ }^{\circ} \mathrm{C}$ であった。今 後, 水温以外の要因が本種の蝟集に与える影響を評価す るため, より広域で消波ブロック周辺や天然岩礁での調 査を実施するとともに，消波ブロックの構造やサイズ， 水深等と本種の蝟集との関連についても調查する必要が ある。

イスズミ科魚類の季節的な蝟集については, カリブ海 の Grammanik Bank での報告がある。 ${ }^{9)}$ Grammanik Bank では, Kyphosus sectatrix が 1 月から 3 月に 200 個 体以上の群れを形成し，産卵を行う。一方，長崎沿岸の ノトイスズミの産卵期は 6 月から 10 月であることか ら, ${ }^{10)}$ 本種が産卵のために消波ブロック周辺に蝟集した とは考えにくい。また, 和歌漁港の消波ブロック周辺で はノトイスズミの主要な慨となるホンダワラ類が豊富に 生えているものの, その他の調查地点では消波ブロック 周辺にホンダワラ類は少ない。それゆえ, 摂慨のために 


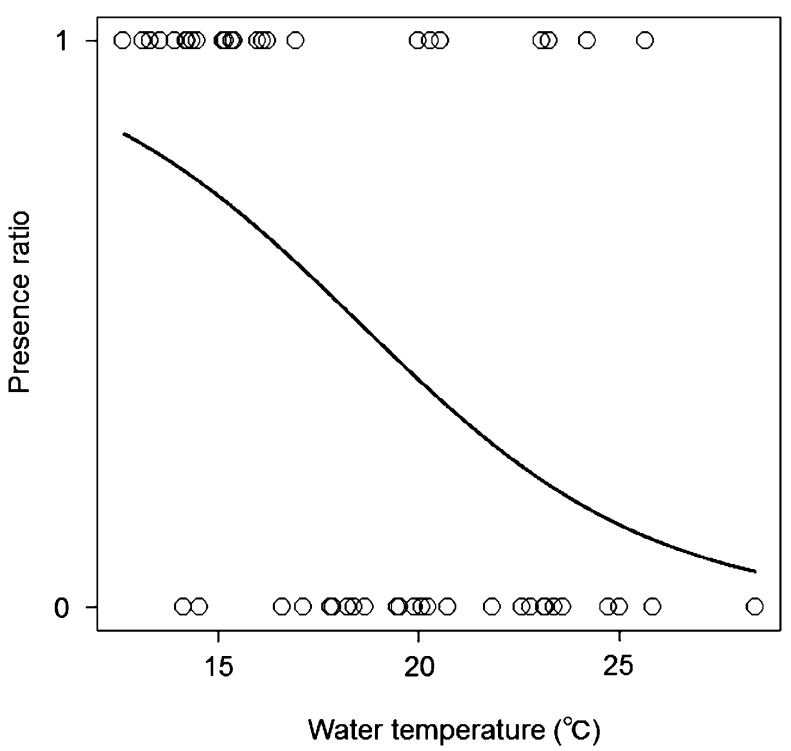

Fig. 3 The relationship between water temperature and the presence ratio of large aggregation $(=200$ individuals or more) in Kyphosus bigibbus at Waka Port, Iki, Nagasaki. The solid line represents the binomial model $(p<0.01)$.

消波ブロック周辺に蝟集しているとも考えにくい。本調 査では, 本種は消波ブロック周辺に群れを形成し, 観察 者が近づくと消波ブロックの隙間に入ることがあった。 このことは，ノトイスズミが消波ブロックをシェルター として利用していることを示唆する。ただし，本種の捕 食者や本種に対する捕食圧の季節変化についての情報は なく，冬季に消波ブロックに蝟集する生態的意義の解明 は今後の重要な課題である。

植食性魚類による海藻類の食害対策は, 植食性魚類の 個体数を対象海域から減らす「除去」, 進入を物理フェ ンスなどで防ぐ「防御」及び採食圧を威嚇等により緩和 させる「分散」の3つのカテゴリーに分けられてお り,6,11)ノトイスズミでは消波ブロック蝟集時に刺網に よる「除去」が可能であることが報告されている。6,8) 本 研究ではノトイスズミの蝟集が九州沿岸各地で起こる可 能性と, 低水温時に高頻度で蝟集が確認できることを明 らかにした。これらの結果は, 本種の蝟集生態を利用し た除去が実施できる海域や期間を選定する上で重要な情 報になる。たたし，イスズミ科魚類はサンゴ礁域では健 全な生態系を維持する上で重要な役割を果たしているこ とが示されている一方で, ${ }^{12)}$ 日本沿岸ではその役割や重 要性は十分には分かっていない。今後, 日本沿岸に招け る本種の生態を解明し, 本種の除去が沿岸生態系に及ぼ す影響を評価した上で，個体数管理を進めていくことが 必要と考える。

\section{謝辞}

壱岐栽培センター所長の山仲洋紀氏, 西日本オーシャ
ンリサーチの渡邊耕平氏には, 野外調査にご協力いただ いた。をた, 壱岐市郷ノ浦町漁業協同組合, 長崎市新三 重漁業協同組合, 長崎市野母崎三和漁業協同組合, 日向 市漁業協同組合ならびに串間市東漁業協同組合には調査 を許可していただいた。(侑)崎陽潜水の兵働真氏には対馬 市に抢ける本種の蝟集情報を提供していただいた。本稿 を執筆するにあたり, 西海区水産研究所業務推進部長の 青野英明博士には有益なご助言をいただいた。ここに記 して, 厚く御礼申し上げる。本研究の一部は「水産庁委 託水産生物の生活史に対応した漁場環境形成推進事業」 により実施したものである。

\section{文献}

1) Sakai K, Nakabo T. Two new species of Kyphosus (Kyphosidae) and a taxonomic review of Kyphosus bigibbus Lacepède from the Indo-Pacific. Ichthyol. Res. 2004; 51: 20-32.

2) Yatsuya K, Kiyomoto S, Yoshimura T. Seasonal changes in dietary composition of the herbivorous fish Kyphosus bigibbus in southwestern Japan. Fish. Sci. 2015; 81: 10251033.

3) 桐山隆哉, 野田幹雄, 藤井明彦. 藻食性魚類数種による クロメの摂食と摂食痕. 水産増殖 2001; 49: 431-438.

4）藤田大介, 野田幹雄, 桑原久美.「海藻を食べる魚たち一 生態から利用まで一」成山堂書店, 東京. 2006.

5) Verges A, Steinberg PD, Hay ME, Poore AG, Campbell AH, Ballesteros E, Heck KL Jr., Booth DJ, Coleman MA, Feary DA, Figueira W, Langlois T, Marzinelli EM, Mizerek T, Mumby PJ, Nakamura Y, Roughan M, van Sebille E, Gupta AS, Smale DA, Tomas F, Wernberg T, Wilson SK. The tropicalization of temperate marine ecosystems: climate-mediated changes in herbivory and community phase shifts. Proc. R. Soc. B 2014; 281: 20140846.

6) 桑原久実. 魚の食害対策に係わる技術と課題. 水産工学 2015; 51: 253-257.

7) Yamaguchi A, Inoue $K$, Furumitsu K, Kiriyama $T$, Yoshimura T, Koido T, Nakata H. Behavior and migration of rabbitfish Siganus fuscescens and grey seachub Kyphosus bigibbus off Nomozaki, Kyushu, tracked by biotelemetry method. Nippon Suisan Gakkaishi 2006; 72: 1046-1056 (in Japanese with English abstract) .

8) 桑原久美, 南里海児, 山仲洋紀. 長崎県壱岐のノトイス ズミを効率良く刺網で漁獲する方法. 日本水産工学会学 術講演会講演論文集 2012; 53-54.

9) Nemeth RS, Kadison E. Temporal patterns and behavioral characteristics of aggregation formation and spawning in the Bermuda chub (Kyphosus sectatrix). Coral Reefs 2013; 32: 1067-1076.

10) Yamaguchi A, Kume G, Yoshimura Y, Kiriyama T, Yoshimura T. Spawning season and size at sexual maturity of Kyphosus bigibbus (Kyphosidae) from northwest Kyushu, Japan. Ichthyol. Res. 2011; 58: 283-287.

11）磯焼け対策ガイドライン．水産庁，東京. 2007.

12) Michael PJ, Hyndes GA, Vanderklift MA, Vergés A. Identity and behaviour of herbivorous fish influence largescale spatial patterns of macroalgal herbivory in a coral reef. Mar. Ecol. Prog. Ser. 2013; 482: 227-240. 